ISSN: 2238-8052

\title{
OS MOBILIZADORES SOCIAIS DE RIACHÃO DO JACUÍPE - BA - ANÁLISE DE UM MOVIMENTO SOCIAL POPULAR EM BUSCA DA CIDADANIA
}

\author{
LOS "MOBILIZADORES SOCIAIS DE RIACHÃO DO JACUÍPE -BA" - ANÁLISIS DE UN MOVIMIENTO \\ SOCIAL POPULAR EN BUSQUEDA DE CIUDADANÍA
}

Abraão Cícero CARNEIROำ

Palavras-chave:

Cidadania,

Mobilizadores

Sociais,

Gestão Pública,

Democracia,

Movimentos Sociais.

Palabras clave:

Ciudadanía,

Mobilizadores

Sociais,

Gestión Pública,

Democracia,

Movimientos

Sociales.

\section{R E S U M O}

0 presente artigo destina-se ao estudo dos Mobilizadores Sociais enquanto movimento social que busca realizar o controle social da gestão pública e o aprimoramento da cidadania na cidade de Riachão do Jacuípe, Bahia. Busca-se analisar as origens do movimento, o (s) impacto (s) na realidade local, a relação com os poderes constituídos e os frutos produzidos. A fim de responder aos questionamentos da pesquisa foi preciso levantar investigação através de bibliografia interdisciplinar, tendo como norte a obra Movimentos Sociais e Redes de Mobilizações Civis de Maria da Glória Gohn, bem como através da análise de documentos produzidos pelo movimento, por entrevistas semiestruturas com atores sociais e com atividades de campo para observar suas articulações. Foram encontradas várias dificuldades desde problemas humanos em quantidade e qualidade, uma relação tensa com o Poder Público e problemas políticos. Todavia, a pesquisa mostrou que o movimento tem procurado inovar e encontrar saídas para os problemas vividos.

\section{R E S U M E N}

El presente artículo se destina al estudio de los "Mobilizadores Sociais" como movimiento social que busca realizar el control social de la gestión pública y el perfeccionamiento de la ciudadanía en la ciudad de Riachão do Jacuípe de Bahia. Se busca analizar los orígenes del movimiento, el (los) impacto (s) en la realidad local, la relación con los poderes constituidos y los frutos producidos. A fin de responder a los cuestionamientos de la investigación fue preciso levantar investigación a través de una bibliografía interdisciplinaria, teniendo como norte la obra "Movimentos Sociais e Redes de Mobilizações Civis" de María de la Gloria Gohn, así como a través del análisis de documentos producidos por el movimiento, por entrevista semiestructura con actores sociales y con actividades de comunicación campo para observar sus articulaciones. Se han encontrado varias dificultades desde problemas humanos en cantidad y calidad, una relación tensa con el Poder Público y problemas políticos. Sin embargo, la investigación mostró que el movimiento ha intentado innovar y encontrar salidas para los problemas vividos.

\section{INTRODUÇÃO}

A palavra cidadania, advém de cidade, mais precisamente das antigas cidades-estados gregas e posteriormente na cidade-estado de Roma, compreendendo o cidadão aquele que tinha a capacidade,

\footnotetext{
${ }^{1}$ Bacharel em Direito pela Universidade do Estado da Bahia. Especialista em Gestão Pública Municipal pela Universidade Federal da Bahia. E-mail: abraaocicero@gmail.com.
} 
dentro de uma lógica de solidariedade social junto a uma população e um espaço/território (cidadeEstado), de participar dos negócios públicos, no caso grego na Ágora, a praça pública, vejamos a lição de MARQUES e MIRAGEM (2014, p. 35)

[...] foram os romanos que, no Ocidente, forjaram o conceito de Estado e do bem comum, que implica também uma ordem pública, pois a cidade (civitas) romana era o locus (lugar) graças ao qual o indivíduo podia se desenvolver livremente, como cidadão, daí a origem do conceito público de cidadania.

No Brasil, o exercício da cidadania pode ser considerado complexo e repleto de desafios, ainda que tenha havido manifestações durante a nossa história o povo foi alijado das grandes decisões políticas, segundo CARVALHO (2002, p.83)

\begin{abstract}
A participação na política nacional, inclusive nos grandes acontecimentos, era limitada a pequenos grupos. A grande maioria do povo tinha com o governo uma relação de distância, de suspeita, quando não de aberto antagonismo. Quando o povo agia politicamente, em geral o fazia como reação ao que considerava arbítrio das autoridades. Era uma cidadania em negativo, se se pode dizer assim. 0 povo não tinha lugar no sistema político, seja no Império, seja na República. O Brasil era ainda para ele uma realidade abstrata. Aos grandes acontecimentos políticos nacionais, ele assistia, não como bestializado, mas como curioso, desconfiado, temeroso, talvez um tanto divertido.
\end{abstract}

Tal fenômeno se explica pelo modelo exploratório do Brasil não somente no aspecto econômico, mas social resultado da escravidão aliadas a práticas autoritárias que deixaram seu marco na construção social e política (CARVALHO, 2002). E tal argumentação se corrobora ao verificarmos que o maior período de democracia brasileira se dá justamente com o advento da Constituição de 1988, com apenas 30 anos de liberdade política.

Em que pese os desafios, todavia a sociedade brasileira não se trata de uma massa "amorfa" ou "inerte", pois segundo GOHN (2010), em sentido contrário os movimentos sociais surgem da articulação popular em torno de uma questão social relevante. Sob essa perspectiva os Mobilizadores Sociais nascem como um movimento em meados dos anos 2000 para prosseguir com os trabalhos de cidadania realizados por padres que chegaram à Paróquia de Riachão do Jacuípe nos anos 1990.

Com base em uma leitura bibliográfica interdisciplinar, tendo como norte a obra Movimentos Sociais e Redes de Mobilizações Civis de Maria da Glória Gohn (2010), foi realizada análise de documentos, entrevista semiestruturada com atores sociais, bem como coleta de dados em trabalho de campo para a disciplina Gestão Pública, Territorialidade e Movimentos Sociais ofertada pelo Programa de Pós-Graduação em Planejamento Territorial da Universidade Estadual de Feira de Santana onde se pretendeu realizar um itinerário da atuação desse movimento social. Buscando compreender quais as origens? Qual o trabalho realizado? Qual impacto na realidade local? Quais as dificuldades encontradas? Qual relação se fez com o Estado? Propondo, portanto, compreender de que maneira os Mobilizadores Sociais podem aperfeiçoar a cidadania local e superar os vícios da gestão pública, sobretudo, o patrimonialismo e o clientelismo. 
Trata-se de um estudo que se reveste de grande importância na medida em que temos no Brasil uma cidadania tardia e de baixa intensidade com grandes desafios a serem alcançados para o amadurecimento da democracia da gestão pública e no alcance de um modelo de gestão societal aliadas as dificuldades particulares da gestão de Riachão de Jacuípe, não obstante muito semelhantes no Brasil como um todo. No âmbito acadêmico, o presente estudo de caso, traz reflexões sobre o exercício da cidadania no Brasil e o aperfeiçoamento de sua democracia. Desse modo, a pesquisa é indicada para estudiosos das Ciências Humanas e Sociais Aplicadas.

0 presente artigo foi divido em 06 tópicos, organizados da seguinte maneira: o primeiro ficou reservado a introdução, com a metodologia, objetivos (específicos e geral), objeto e com conceitos básicos sobre o movimento social e a cidadania; o tópico 2 traz ao leitor uma crítica sobre o papel da cidadania na gestão pública brasileira; o terceiro aborda as raízes dos Mobilizadores Sociais, mas também o "solo", o contexto; o item 4 aborda as ações empreendidas pelo Movimento e seus impactos; o item 5 aborda a relação que se estabeleceu entre o movimento e o Estado; e o tópico 6 é dedicado as considerações finais.

\section{CIDADANIA E GESTÃo PÚBLICA}

Se o exercício da cidadania encontrou dificuldades em nosso país, por outro lado, e como efeito disto, as práticas de gestão pública no Brasil ficaram marcadas pelo traço do autoritarismo, do patrimonialismo e do clientelismo.

Partindo do período republicano, que significa o governo da coisa pública, não teve o mesmo peso político visto na Europa onde representou a derrubada do Antigo Regime. Tendo como marco a revolução Francesa, houve a inserção dos valores do iluminismo, a separação dos poderes estatais, a implementação dos direitos civis e da proteção da propriedade privada.

No Brasil o movimento foi diverso, pois segundo FERNANDES (2006), a elite local ao suplantar o pacto colonial não fez sua revolução burguesa aos moldes europeus, mas se aliou a velha oligarquia rural, muito também porque os burgueses locais tinham suas origens na economia rural e o modelo de capitalismo dependente não fomentou uma burguesia revolucionária que pusesse fim ao regime das oligarquias rurais,

(...) podia discordar da oligarquia ou mesmo opor-se a ela. Mas fazia-o dentro de um horizonte cultural que era essencialmente o mesmo, polarizando em torno de preocupações particularistas e de um entranhado conservantismo sociocultural e político. O conflito emergia, mas através de discórdias circunscritas, principalmente vinculadas a estreitos interesses materiais, ditados pela necessidade de expandir os negócios. Era um conflito que permitia fácil acomodação e que não podia, por si mesmo, modificar a história. Além disso, o mandonismo oligárquico reproduzia-se fora da oligarquia (FERNANDES, 2006, p. 205). 
De caráter conciliador, houve um convívio do velho com o novo, da nobreza e da oligarquia rural com o capitalismo liberal nascente, mantendo a estrutura social e econômica vigente, sobretudo a famigerada escravidão (MAZZE0, 1989).

Não obstante, de caráter, segundo MAZZEO (1989), realizado "pelo alto", ou seja, conduzido pela elite e abstraída de qualquer concessão política-filosófica de direitos ao povo. Neste sentido, a participação popular fora suprimida no processo, estranho, portanto, do ideal pela qual propugnava os liberais franceses. Construiu-se um liberalismo tão somente no aspecto econômico e adaptado aos interesses dos mandatários locais, vejamos:

Diversa da liberdade pessoal que o universalismo burguês apregoava, a estrutura escravista criava, dentro das relações sociais e no aspecto ideológico, a manipulação que sustentava o controle o alijamento social. "Para as elites que tiveram a iniciativa e o controle do movimento, liberalismo significava apenas liquidação dos laços coloniais. Não pretendiam reformar a estrutura de produção nem a estrutura da sociedade. Por isso a escravidão seria mantida, assim como a economia de exportação (MAZZEO, 1989, p. 120).

Configurado e acomodado a ser uma economia periférica que fornecia basicamente produtos agrícolas e minerários, no Brasil não ocorreu um processo de industrialização. Assim, era muito mais cômodo e lucrativo a manutenção da velha estrutura agroexportadora produzida com mão-de-obra escravista, sem a sua substituição pelo trabalho livre. Forjou-se um Estado abstraído dos direitos de liberdade, de cidadania e não obstante reprimia violentamente sua população. Um Brasil negado aos brasileiros. Nesse modelo, o povo era visto com desconfiança e medo, conforme descrito abaixo por MAZZEO (1989):

Desse modo, a proposta de uma revolução anticolonial, não ultrapassa as fronteiras de uma duvidosa emancipação política. A inexistência de condições históricas que direcionassem a uma ruptura concreta, de cunho revolucionário, com a estrutura sócio-econômica colonial, possibilita que a burguesia latifundiária assuma o processo da independência e, posteriormente, crie um aparelho do Estado dentro de suas diretrizes ideológicas, com o cuidado permanente de afastar quaisquer iniciativas que apontassem para o "perigo" de transformações mais radicais. Como acentua Emília Viotti, é a aversão às formas democráticas de governo, a desconfiança no povo, composto em sua maioria por escravos, que poderiam pôr em xeque a escravidão, o fator que levará a "classe dominantes" brasileira a contemporizar o máximo possível com a monarquia portuguesa (MAZZEO, 1989, p 91.).

Tal simbiose manteve as arcaicas estruturas sociais vigentes de priscas eras coloniais o que gerou a política dos governadores, a política do Café com Leite e o coronelismo. Estrutura política que subjugava a vontade popular e sufocava qualquer ato de cidadania, vejamos sua descrição:

Quem organizava a vida política, diretamente no contato com a população, nos municípios era a figura carismática do "coronel". 0 coronel, apesar do nome, era um líder civil, comumente um fazendeiro que dominava a política local. Ele era o único elo entre a população e o poder estatal. 0 coronel garantia os votos locais do presidente do Estado, em troca do apoio do governador à sua liderança política no seu município (JUNIOR, 2006, p. 17). 
Com o objetivo de enfrentar as velhas práticas do patrimonialismo, no governo Vargas, por intermédio do DASP (Departamento de Administração do Serviço Público), foi realizada a primeira reforma da Administração Pública, a Reforma Burocrática, buscando dar maior racionalidade e organização à administração com a implantação de concursos públicos, padronização de atos administrativos e criação de uma tecnocracia independente da política. A burocracia visava uma modernização da administração pública adequando-a para os novos paradigmas de uma sociedade industrial e urbana que se emergia à época (PINHO ,1998).

Contudo, com a burocracia houve um enrijecimento da estrutura pública, tornando-a extremamente formalista e ineficaz. Tratando-se de um modelo autorreferenciado, ou seja, que não colocava o cidadão no centro das atenções. Sob esse cenário e inspirado em reformas de países de cultura inglesa, foi implementado, na década de 1990 na América Latina, a Reforma Gerencial da administração pública que consistiu na aplicação de ferramentas típicas do setor privado no Estado visando uma maior eficiência dele, vejamos a opinião de:

(...) a reforma gerencial busca aumentar a eficiência e a efetividade dos órgãos ou agências do Estado por meio da descentralização; fortalecer a capacidade do Estado de promover o desenvolvimento econômico e social através da garantia dos contratos e assegurar o caráter democrático da administração pública com um serviço orientado para o cidadão-cliente e a responsabilização do servidor público pelos seus resultados (MATIAS-PEREIRA, 2016, p.61).

Esse modelo, por óbvio, deixou muitas críticas ao comparar o Estado como uma empresa e os cidadãos como clientes. São instituições diferentes e com objetivos diferentes, ainda que seja possível aprender com ambos, porém sem tentar desvirtuá-los, a crítica de MITZNBERG (1998) é bem elucidativa:

Os negócios não são totalmente virtuosos; nem os governos são totalmente viciosos. Cada qual tem seu lugar em uma sociedade equilibrada, juntamente com as organizações cooperativas e as sem proprietários. Não quero comprar carros do governo, nem receber policiamento da General Motors (MITZNBERG, 1998, p. 160).

Se tais modelos de Administração foram implementados, é que porque traços do patrimonialismo não foram superados, pelo contrário os modelos burocrático e gerencial foram aplicados visando superar os vícios da gestão pública, porém não foram construídos de acordo com a realidade brasileira, mas consubstanciados em fenômenos aplicados em outros países e replicados no país.

Desse modo, decorrente do contexto sócio histórico brasileiro, no caso concreto resultou em reformas que não foram capazes de suplantar completamente o patrimonialismo e o clientelismo. PINHO (1995) afirma que as velhas práticas nunca foram superadas porque se mostraram ao longo do tempo bastantes resistentes e capazes de se "atualizarem" perante as novas realidades construídas permanecendo vivas na vida pública nacional, conforme descrição abaixo: 
O que se tem assistido é uma impressionante resiliência do patrimonialismo, capaz de absorver mudanças modernizantes na sociedade brasileira e de se amoldar à nova situação. Talvez pudéssemos pensar em um patrimonialismo camaleônico que consegue não só sobreviver como, ao que parece, se reforçar, mesmo sofrendo a ordem econômica mudanças modernizantes apreciáveis (PINHO, 1995, p 72).

Importante destacar que a reforma gerencial foi implementada no Brasil poucos anos após a redemocratização. E esse fato é relevante, pois com a nova Constituição de 1988 foi permitido além do voto, uma série de mecanismos para o cidadão participar com maior vigor na vida pública.

A respeito das novas possibilidades de participação popular oriundas da Constituição Federal, BRITO (1992) aponta que há normas que permitem o controle social, ou seja, a fiscalização por parte dos cidadãos seja de modo individual ou coletivo (associações, movimentos, sindicatos etc) buscando satisfação daqueles que se obrigam a cuidar do que é público; mas também a participação popular que a seu turno garantem a participação direta dos cidadãos na formulação de políticas públicas.

Exemplos não faltam, a título de controle social se pode citar o art. 5ํㅜ, XXXIII² da Constituição que permite a qualquer brasileiro obter informações dos órgãos públicos ou de participação popular quando a Carta Magna exige a participação da comunidade na formulação das políticas públicas de saúde (art. 198, III) ${ }^{3}$.

A promulgação da nova Constituição trouxe um novo ar para o exercício da cidadania, pelo menos no aspecto legal-formalista, pois contemporânea a mesma, estabeleceu-se no Brasil e no mundo o neoliberalismo. Corrente política que prega um ideal de Estado mínimo e com menos direitos, contrapondo ao próprio ideal do liberalismo clássico, ou seja, nesta nova edição da sociedade liberal há tão somente o caráter econômico em detrimento do político filosófico, reeditando o processo liberal histórico brasileiro:

Não é demais lembrar que é originária do liberalismo a idealidade do "bem-estar" e o princípio da "igualdade formal". Hayek - o apóstolo do neoliberalismo -reserva para o Estado, porém, somente as funções de polícia e de caridade. Para ser coerente com tal receituário, o discurso neoliberal no seu extremo [...] ataca as liberdades formais, porque elas abrigam a possibilidade concreta de tornar as promessas de direitos, constantes na Constituição, realizáveis, pelo constrangimento do movimento econômico em direção a determinados fins (GENRO 2002, p. 105).

Contrapondo ao ideário constitucional, o desafio posto aos governantes foi equilibrar uma sociedade de direitos, garantindo-os frente as necessidades de reformas constantes que o mercado sempre exigia:

A questão democrática está, hoje acossada pela seguinte indagação dos seus gestores neoliberais: como manter um Estado capaz de legitimar as reformas neoliberais,

\footnotetext{
2 Art. 5ơ, XXXIII da Constituição Federal: todos têm direito a receber dos órgãos públicos informações de seu interesse particular, ou de interesse coletivo ou geral, que serão prestadas no prazo da lei, sob pena de responsabilidade, ressalvadas aquelas cujo sigilo seja imprescindível à segurança da sociedade e do Estado;.

3 Art. 198, III da Constituição Federal: Art. 198. As ações e serviços públicos de saúde integram uma rede regionalizada e hierarquizada e constituem um sistema único, organizado de acordo com as seguintes diretrizes: (...) III- participação da comunidade.
} 
reduzindo a potência moral dos valores que informam o Direito moderno? (GENRO, 2002, p. 96).

Houve, assim, um esvaziamento do conceito de cidadão e da própria Constituição, reduzindo-a e renegando cidadãos a meros expectadores de promessas de direitos não cumpridos e destinando aos desvalidos o mero assistencialismo: "Os excluídos, por esta visão pragmática, deixam de "contar" como cidadãos com direitos e passar a ser alvos de políticas de "compensação" (GENRO 2002, p. 97).

Ademais, a sociedade de massas e do consumo desenfreado contribuiu para deteriorar a figura do cidadão, transformando-o em mero consumidor. E neste mundo dos desejos vendidos, modas introduzidas por meio da publicidade conduz a uma alienação detectada por SANTOS (2011) que rompe com os laços de solidariedade entre as pessoas. Tornando-as imediatistas e individualistas, algo que SANTOS (2011) entende que retira a própria consciência, pois é criado um padrão de vida que não está ao alcance de todos gerando uma insatisfação constante sobre o consumo e não sobre o direito:

Em lugar do cidadão surge o consumidor insatisfeito e, por isso, voltado a permanecer consumidor. Sua dependência em relação aos novos objetos limita sua vocação para obter uma individualidade e reduz a possibilidade dos encontros interpessoais direto e enriquecedores, porque simbólicos em sua própria origem. A comunicação entre as pessoas é frequentemente intermediada por coisas. Frequentemente os movimentos de massa também se esgotam nas coisas, tendo uma lógica mais instrumental que existencial. As mobilizações são locais ou setoriais. (...) A força da alienação vem dessa fragilidade dos indivíduos, quando apenas conseguem identificar o que os separa e não o que os une (SANTOS 2011, p. 93).

Desse modo, a nova Constituição e as reformas como descritas nos parágrafos anteriores não trouxeram uma cidadania plena, mas reforçaram o traçado histórico rígido de autoritarismo, diagnóstico contemplado por Paula (2016, p. 115)

$\mathrm{Na}$ história das reformas brasileiras, as dimensões econômico-financeira e institucional-administrativa sobrepujaram a dimensão sociopolítica. Dessa forma, não foi possível conciliar os dois aspectos que circundam o exercício da cidadania: a inclusão socioeconômica, que abrange direitos constitucionais como trabalho, educação e saúde e a inclusão sociopolítica, que se refere à participação dos cidadãos nas decisões de natureza pública que afetam a vida social no presente e no futuro.

Sob esses cenários desafiadores que a autora acima citada propõe um novo modelo de gestão pública, denominando de societal, um que contemple o povo nas decisões públicas, vejamos:

A vertente societal ainda não definiu completamente sua visão de desenvolvimento, mas tende a partilhar de um novo conceito que enfatiza a qualidade de vida e a expansão das capacidades humanas, redefinindo o que entendemos por privação e bem-estar, além de reformular as práticas e políticas que conduzem a isso. Assim, o desenvolvimento é interpretado com a busca de respostas criativas para problemas que envolvem escassez de recursos e que podem ser resolvidos através do estímulo ao potencial produtivo e à participação cidadã (PAULA, 2016 p. 158).

Neste ínterim, tendo em vista a baixa cidadania brasileira e a ausência de efetivos canais de participação/controle popular que viabilizem um modelo de gestão pública popular, os movimentos 
sociais nunca deixaram de atuar, sempre buscando, sob diversos métodos de atuação, a efetivação de uma sociedade democrática:

A presença dos movimentos sociais é uma constante na história política do país, mas ela é cheia de ciclos, com fluxos ascendentes e refluxos (alguns estratégicos, de resistência ou rearticulação em face à nova conjuntura e às novas forças sociopolíticas em ação). O importante a destacar é esse campo de força sociopolítico e o reconhecimento de que suas ações impulsionam mudanças sociais diversas (GOHN 2010, p. 41).

Um modelo que implique em uma participação efetiva da população é um desafio a ser construído, sob esses aspectos e tendo como objeto de estudo os Mobilizadores Sociais, propõe-se a investigar o papel deste movimento social na cidade de Riachão do Jacuípe para dissipar os vícios da gestão pública e propor uma cidadania plena.

\section{RAÍZES DOS MOBILIZADORES SOCIAIS}

Apenas apontar a realidade da cidadania brasileira, a ausência de uma gestão pública societal ou que a sociedade não é uma massa inerte não são suficientes para justificar as origens dos "Mobilizadores Sociais". Foi preciso investigar as "raízes" do movimento, compreendendo as razões que de fato impulsionaram cidadãos a saírem de suas vidas privadas para cuidar do que é público, mas também o "solo", ou seja, o contexto socioeconômico que fomentou a articulação social.

Distante 193 km da capital Salvador, Riachão do Jacuípe se localiza no nordeste baiano, território da Bacia do Jacuípe, clima semiárido. Segundo dados do IGBE (2010) a cidade possui uma população estimada em 2018 em 33.403 (trinta e três mil quatrocentos e três) habitantes e um IDH (Índice de Desenvolvimento Humano) de 0.628, ou seja, considerado baixo, na Figura 1, encontra-se a localização do município.

Figura 1. Localização de Riachão do Jacuípe/BA.

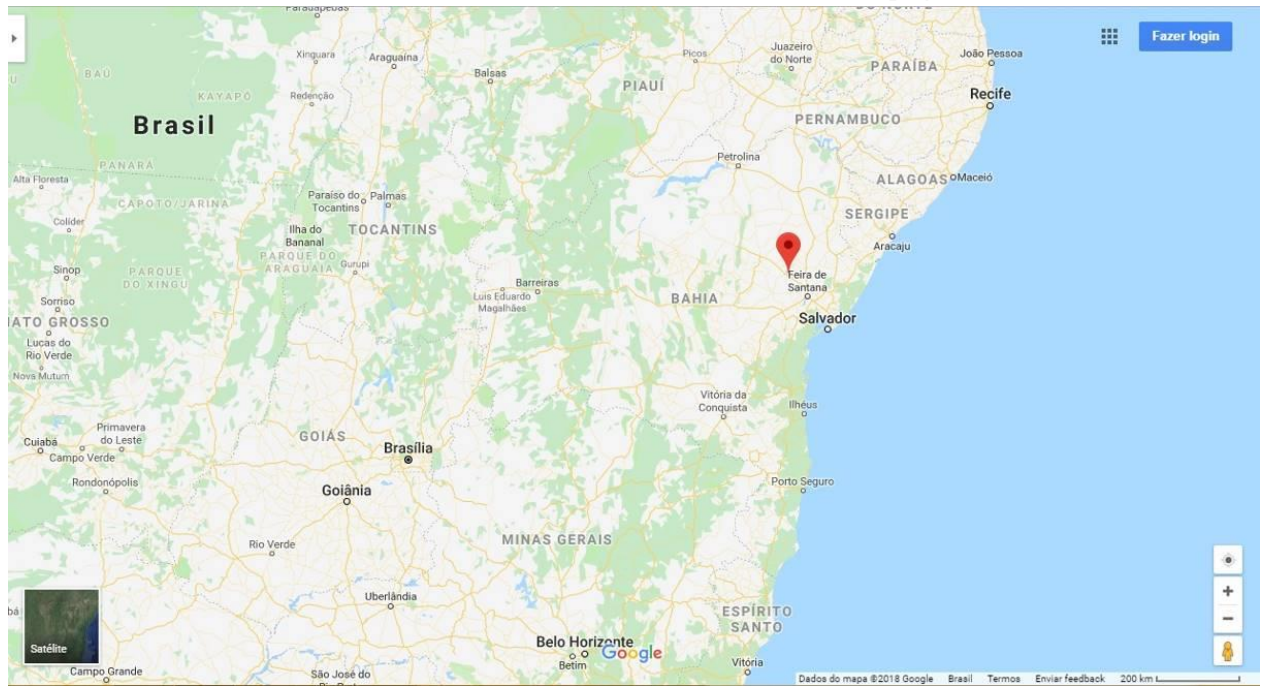

Fonte: Google Maps. https://www.google.com.br/maps/search/riachao+do+jacuipe/@-11.8066071,39.4022931,13z. 
Sendo a cidade a origem etimológica e histórica da cidadania, conforme descrito na introdução, a delimitação do "solo", ou seja, das característica de Riachão do Jacuípe é importante para descrever a situação no espaço do evento em estudo, sobretudo ao leitor, contudo, não se faz necessário avançar ainda mais na caracterização geográfica do município a fim de evitar caricaturas do problema pelo fato da cidade-objeto se localizar no semiárido e todo o senso comum relacionado ao Nordeste, pois ao longo do texto se percebe que as dificuldades de exercício da cidadania são constantes em todo o país. Os Mobilizadores Sociais surgem na primeira metade da década dos anos 2000, através de pessoas interessadas no controle social da gestão pública municipal de Riachão do Jacuípe, conforme pode ser observado através da finalidade social obtida no blog do movimento:

o Grupo Mobilizadores Sociais é uma organização não governamental independente e autônoma, pessoa jurídica de direito privado com fins não lucrativos. Composto por pessoas amigas, interessadas em oferecer voluntariamente seu tempo, seu talento, competências e habilidades para a construção de uma sociedade mais justa. Os Mobilizadores Sociais não têm vínculo religioso ou político-partidário, nossa organização apoia ações sociais que estimulem a autonomia das pessoas e das comunidades para transformar a sua realidade, promovendo a fiscalização dos recursos público, a garantia dos direitos humanos e sociais, além de iniciativas diversas que visam o desenvolvimento integral da sociedade jacuipense. Acreditamos que o combate à corrupção e a tudo o que é contrário ao interesse da população é possível a partir da união de pessoas a favor da ética e da moral ${ }^{4}$.

A finalidade do movimento acima narrada pode demonstrar um tanto quanto apática, sobretudo, aqueles familiarizados as dicotomias políticas contemporâneas do tipo: direita x esquerda, mercado x social, liberalismo x socialdemocracia etc. Contudo, os Mobilizadores Sociais trazem consigo a práxis e a teoria da Doutrina Social da Igreja o que lhes permitem uma abertura e um diálogo mais aberto, longe das categorizações políticas:

A Doutrina Social da Igreja não é uma 'terceira via' entre capitalismo liberalista e coletivismo marxista, nem sequer uma possível alternativa a outras soluções menos radicalmente contrapostas: ela constitui por si mesma uma categoria. Não é tampouco uma ideologia, mas a formulação acurada dos resultados de uma reflexão atenta sobre as complexas realidades da existência do homem, na sociedade e no contexto internacional, à luz da fé e da tradição eclesial (JOAO PAULO II, Papa 1987).

Segundo depoimento do ator social do movimento e professor, José Avelange, as raízes do movimento decorreram da necessidade de prosseguir com uma caminhada de cidadania empreendida por padres ligados a causas populares que chegaram em Riachão do Jacuípe na década de 1990 que questionaram as velhas práticas políticas ainda presentes na vida local como o clientelismo, paternalismo e o patrimonialismo, segue o relato do ator social, José Avelange:

Os Mobilizadores Sociais surgiram para retomar um trabalho que começou em Riachão do Jacuípe por incentivo do padre bastante conhecido aqui na cidade, o Pe. Silvino, que vinha com uma formação voltada pelo Concílio Vaticano II, um evento da Igreja Católica, que significou uma abertura para os temas sociais (Entrevista realizada dia 23 de novembro de 2018).

\footnotetext{
${ }^{4}$ Disponível em: http://mobilizadores.blogspot.com, s.d. Acesso em jun. 2019.
} 
Esse relato do ator social é corroborado pela dissertação de mestrado realizada por SILVA (2005) onde descreve o papel da Igreja naquele período na construção de uma nova visão política:

Dessa forma, padre Silvino tentava implantar entre os jacuipenses, novo comportamento, novas práticas sociais com um discurso carregado de signos libertários que desqualificavam a cultura política e religiosa local. 0 costume aparece em suas falas como sinônimo do atraso inculto, consubstanciado na ideia de que as pessoas não sabiam escolher seus representantes, por isso, a cidade não se desenvolvia (SILVA, 2005, p. 106)

É bem verdade que esse fenômeno explicitado por José Avelange não se trata de um caso isolado, mas decorrente da atuação da Igreja Católica nas décadas de 1970/1980, em plena ditadura, efetuado por padres e bispos ligados as Comunidades Eclesiais de Base, assim como por outros movimentos urbanos da época, fundamentais para a redemocratização do país, vejamos a análise de FERNANDES (2004, p.77)

Dentre os movimentos sociais importantes que emergem a partir da década de 70 , alguns se destacam, como as Comunidades Eclesiais de Base (CEBs), o movimento feminista, as associações ecológicas, o movimento do custo de vida e as associações de moradores. [...] No que se refere à Igreja, sem o apoio logístico das paróquias a grande maioria das manifestações não teria local para reuniões, e menos ainda possibilidade de comunicação.

Ainda que tenha surgido "tardiamente" na cidade de Riachão do Jacuípe, pode-se afirmar que as atividades políticas da Igreja tiveram seus reflexos e impulsionaram um novo tipo de militância política. Floresceu uma reflexão a respeito das velhas práticas políticas e do papel do cidadão no contexto de superação desses males. Essa experiência serviu de substrato para as ações que seriam implementadas no município nos anos seguintes, conforme relato do ator social José Avelange:

Então, quando ele termina sua formação de padre (Pe. Silvino) e vem trabalhar com outros da mesma linha, como o Pe. Ionilton, que depois veio se tornar bispo da Amazônia, eles resolvem educar a população jacuipense a partir dos paroquianos para a cidadania. Então no início da década de 1990 isso começou a acontecer, deu resultado e porque as pessoas começaram a questionar o próprio coronelismo que estava mais ou menos presente na cidade e isso quase que desapareceu nos anos 2000. Notando isso a gente percebeu que era preciso fazer alguma coisa e surgiu então os Mobilizadores Sociais com esse propósito de formar uma caminhada de cidadania e de fiscalização dos recursos públicos do município. (Entrevista realizada dia 23 de novembro de 2018).

Relato confirmado pelo ativista social, Vital Marinho:

Começamos aqui na década de 1990, junto com a pastoral da juventude da Igreja Católica, um grupo que começou a fazer um pouco dessa formação. Somos aqui uma cidade do interior, deste estilo paroquiano no seu sentido estrito mesmo. E que era governado pelos coronéis. Com a vinda do Pe. Silvino começamos a ter contato com a pastoral da juventude, com as orientações, ele veio trazer a Doutrina Social da Igreja (Entrevista realizada dia 16 de julho de 2019).

A nova consciência empreendida pelos religiosos serviu de fomento para a atuação dos Mobilizadores, pois compreenderam que o modo de gerir as coisas públicas estavam incorretas e que 
não havia espaço para a concretização da cidadania. A crítica do cidadão é um fenômeno interessante, sobretudo, quando ressoa e permite a união com outros cidadãos também indignados e criam uma relação de solidariedade social.

\section{AÇõES EMPREENDIDAS}

Para fins didáticos é possível dividir a atuação dos Mobilizadores Sociais em dois momentos: o primeiro que remonta desde as suas origens até meados de 2013, onde consistiu num forte trabalho de controle social da gestão pública e em um segundo momento pós-2013 voltado para ações de educação, ou seja, visando uma formação para a cidadania para os atuais e novos atores sociais. Inspirados pelos trabalhos realizados pelos padres na década de 1990, cidadãos jacuipenses se reúnem buscando romper as velhas práticas da política local para buscar uma maior transparência da gestão pública e o exercício do controle social.

A atuação teve como base o disposto no art. $31^{5}$ da Constituição Federal onde determina que durante 60 (sessenta dias) anualmente as contas públicas estarão a disposição de qualquer contribuinte para exame e apreciação, bem como no art. 17 da Lei Orgânica Municipal de Riachão do Jacuípe $^{6}$ que regulamenta esse prazo partir de 15 (quinze) de abril de cada ano, no horário de funcionamento da Câmara Municipal e em local de fácil acesso.

Desse modo, os mobilizadores articularam equipes para a fiscalização das contas públicas, contando com o apoio da comunidade local, segue o relato de José Avelange:

O movimento social ali pelos anos de 2009, 2010... até acredito que em 2013 mais ou menos tinha uma atuação muito forte na fiscalização das contas públicas e porque nós tínhamos mão-de-obra para isso. 0 grupo estava com número de participantes razoavelmente grande para os padrões de participação local. Então se estabelecia que uma equipe com tais e tais pessoas iriam fazer esse trabalho tal dia da semana, outra equipe iria tal dia (Entrevista realizada dia 23 de novembro de 2018).

Tal esforço empreendeu em ações derivadas como ofícios cobrando ações da prefeitura e reclamações direcionadas ao Ministério Público perante irregularidades encontradas na Prefeitura e na Câmara Municipal a exemplo da contratação de funcionários fantasmas, licitações fraudulentas, pagamento de diárias sem comprovação e contratação de serviços em valores exorbitantes aos praticados no mercado.

\footnotetext{
${ }^{5}$ Art. 31. Constituição Federal. A fiscalização do Município será exercida pelo Poder Legislativo Municipal, mediante controle externo, e pelos sistemas de controle interno do Poder Executivo Municipal, na forma da lei. (...)

$\S 3^{\circ}$. As contas dos Municípios ficarão, durante sessenta dias, anualmente, à disposição de qualquer contribuinte, para exame e apreciação, o qual poderá questionar-lhe a legitimidade, nos termos da lei.

${ }^{6}$ Art. 17. Lei Orgânica Municipal. As contas do Município ficarão à disposição dos cidadãos durante 60 (sessenta) dias, a partir de 15 (quinze) de abril de cada exercício, no horário de funcionamento da Câmara Municipal, local de fácil acesso ao público.

$\S 1$ ㅇ. A consulta às contas municipais poderá ser feita por qualquer cidadão, independentemente de requerimento, autorização ou despacho de qualquer autoridade, na forma prevista em regulamento.
} 
As Figuras 2 e 3, respectivamente, correspondem a atuação na fiscalização das contas públicas e em um ofício destinado a Prefeitura Municipal cobrando reclamações produzidas pelos cidadãos por intermédio dos Mobilizadores.

Figura 2. Realização da análise das contas públicas.

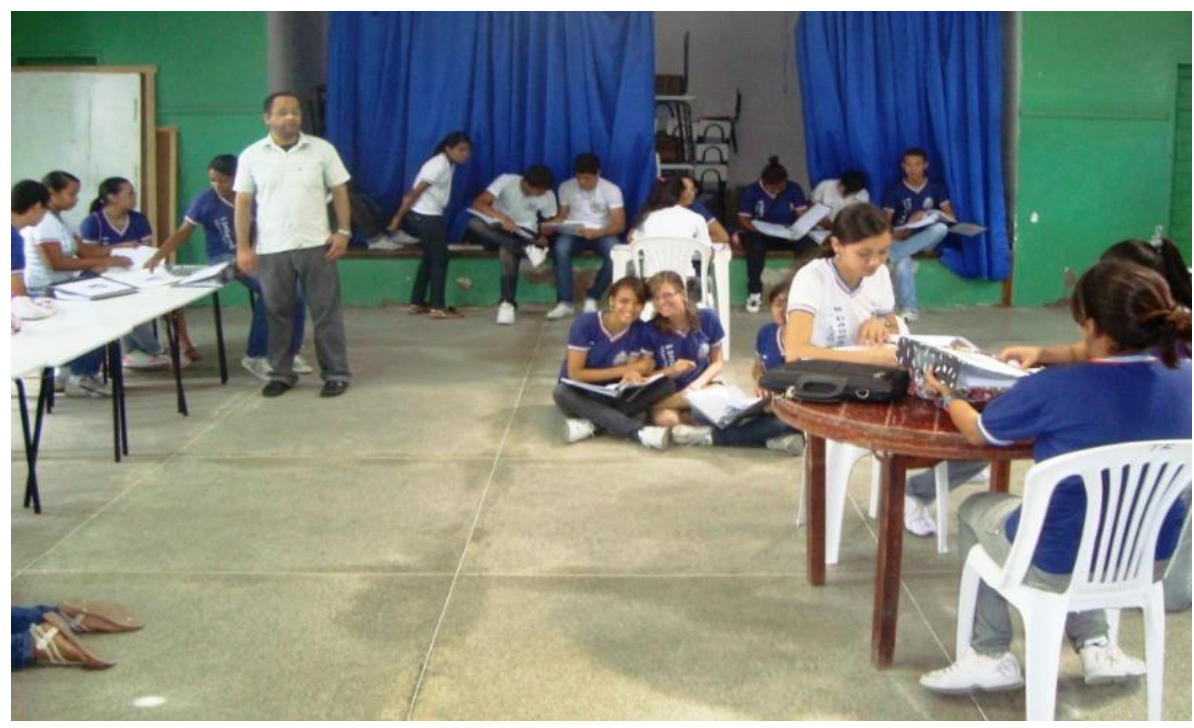

Fonte: Disponível no site do movimento social.

Figura 3. Ofício expedido à Prefeitura de Riachão do Jacuípe.
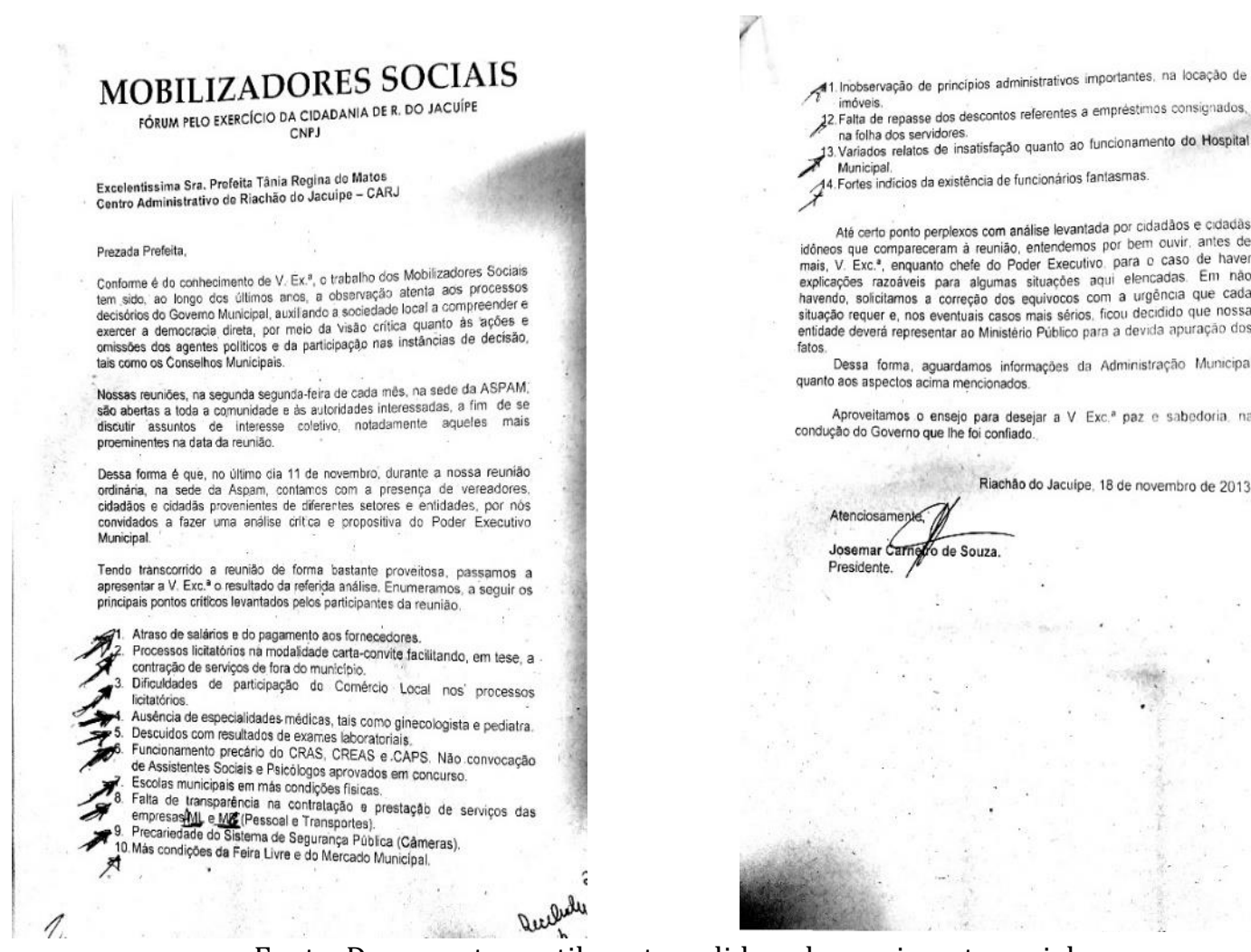

Fonte: Documento gentilmente cedido pelo movimento social. 
O referido ofício acima listou uma série de questões críticas a respeito da gestão local à época pontuados pelos cidadãos presentes na reunião do movimento ocorrido em 11 de novembro de 2013, das quais foram transcritas abaixo:

1. Atraso de salários e do pagamento aos fornecedores;

2. Processos licitatórios na modalidade carta-convite facilitando, em tese, a contratação de serviços fora do município;

3. Dificuldades de participação do comércio local nos processos licitatórios;

4. Ausência de especialidades médicas, tais como ginecologista e pediatra;

5. Descuidos com resultados de exames laboratoriais;

6. Funcionamento precário do CRAS, CREAS e CAPS. Não convocação de Assistentes Sociais e Psicólogos aprovados em concurso;

7. Escolas municipais em más condições físicas;

8. Falta de transparência na contratação e prestação de serviços das empresas AML e MC (pessoal e transportes);

9. Precariedade do Sistema de Segurança Pública (câmaras);

10. Más condições da feira livre e do mercado municipal;

11. Inobservação de princípios administrativos importantes na locação de imóveis;

12. Falta de repasse dos descontos referentes a empréstimos consignados na folha dos servidores;

13. Variados relatos de insatisfação quanto ao funcionamento do Hospital Municipal;

14. Fortes indícios da existência de funcionários fantasmas.

Da listagem acima de reclames e de problemas para entrar na agenda de formulação de políticas públicas local, a gestão da época produziu ofício (imagem abaixo) destinado ao movimento social fornecendo suas razões. Ainda que não tenha sido sanados no momento (o que não foi objeto da presente pesquisa), é relevante o feito na medida em que forçou a Prefeitura a prestar esclarecimentos aos cidadãos. Uma ação relevante do movimento social, sobretudo, pelo contexto histórico local e nacional do modelo autoritário de gerir a coisa pública. Abaixo (Figura 4), o ofício redigido pela Prefeitura Municipal encaminhado ao movimento social. 
Figura 1. Parcial do ofício produzido pela Prefeitura e encaminhado ao movimento social.

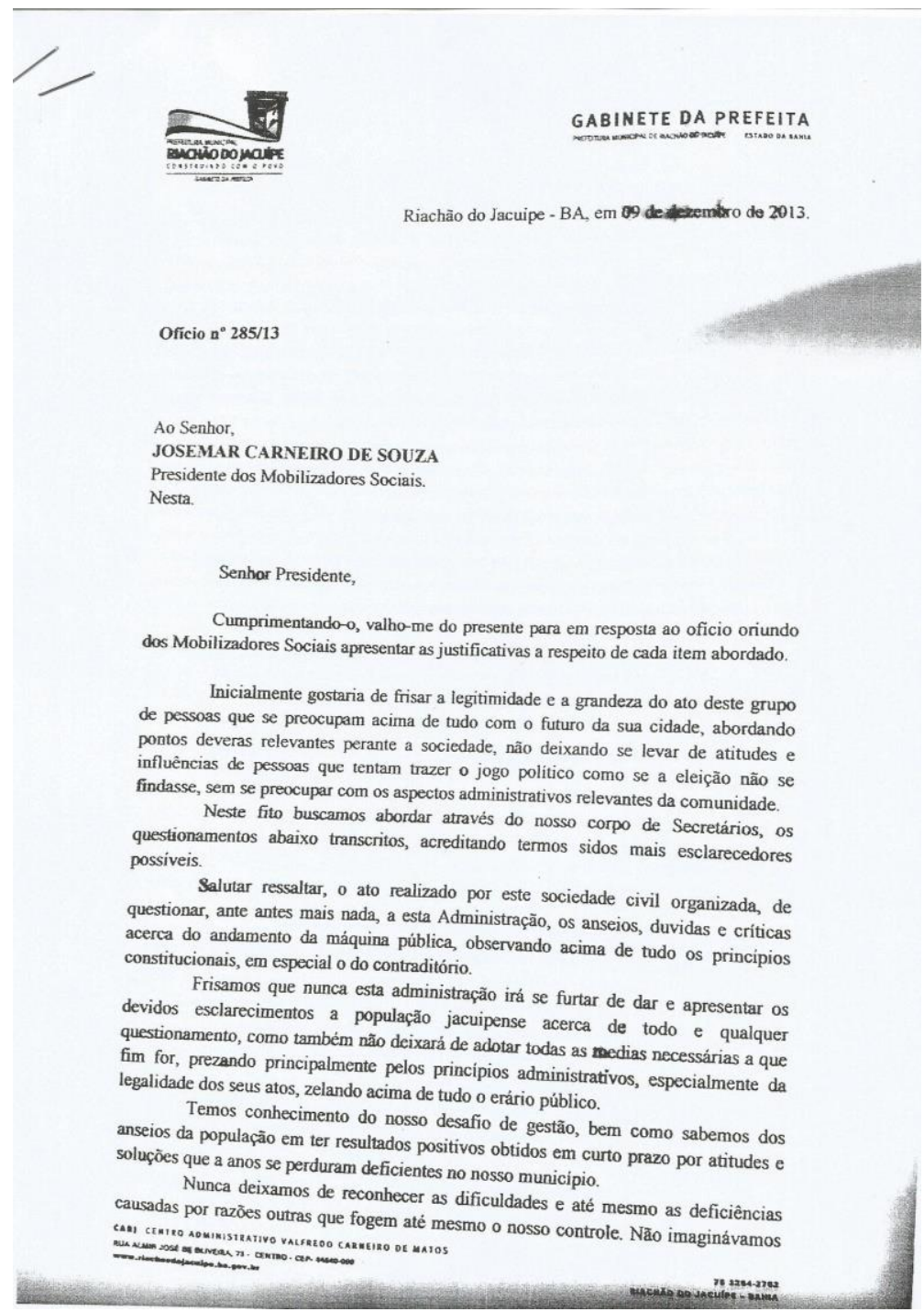

Fonte: Documento gentilmente cedido pelos Mobilizadores Sociais.

Todavia, as ações do movimento social vão para além da fiscalização das contas públicas e das denúncias de prováveis ilícitos, os Mobilizadores atuaram no campo da comunicação social produzindo material educativo sobre o papel do movimento e da cidadania por intermédio de um blog na internet o: "http://mobilizadores.blogspot.com/", bem como, através da publicação de um informativo entre os anos de 2010/2011, tendo como público alvo o cidadão comum.

Redigido em linguagem acessível, o jornal "Informe Cidadão", trazia artigos conscientizando sobre a importância da cidadania, críticas à gestão pública, informes de outros movimentos sociais locais (sindicatos, organizações assistenciais, eventos culturais etc.), os resultados dos Mobilizadores e denúncias das irregularidades detectadas pelo movimento social. Na Figura 5, encontram-se exemplares distribuídos para a população jacuipense. 
Figura 2. Exemplares da publicação "Informe Cidadão".

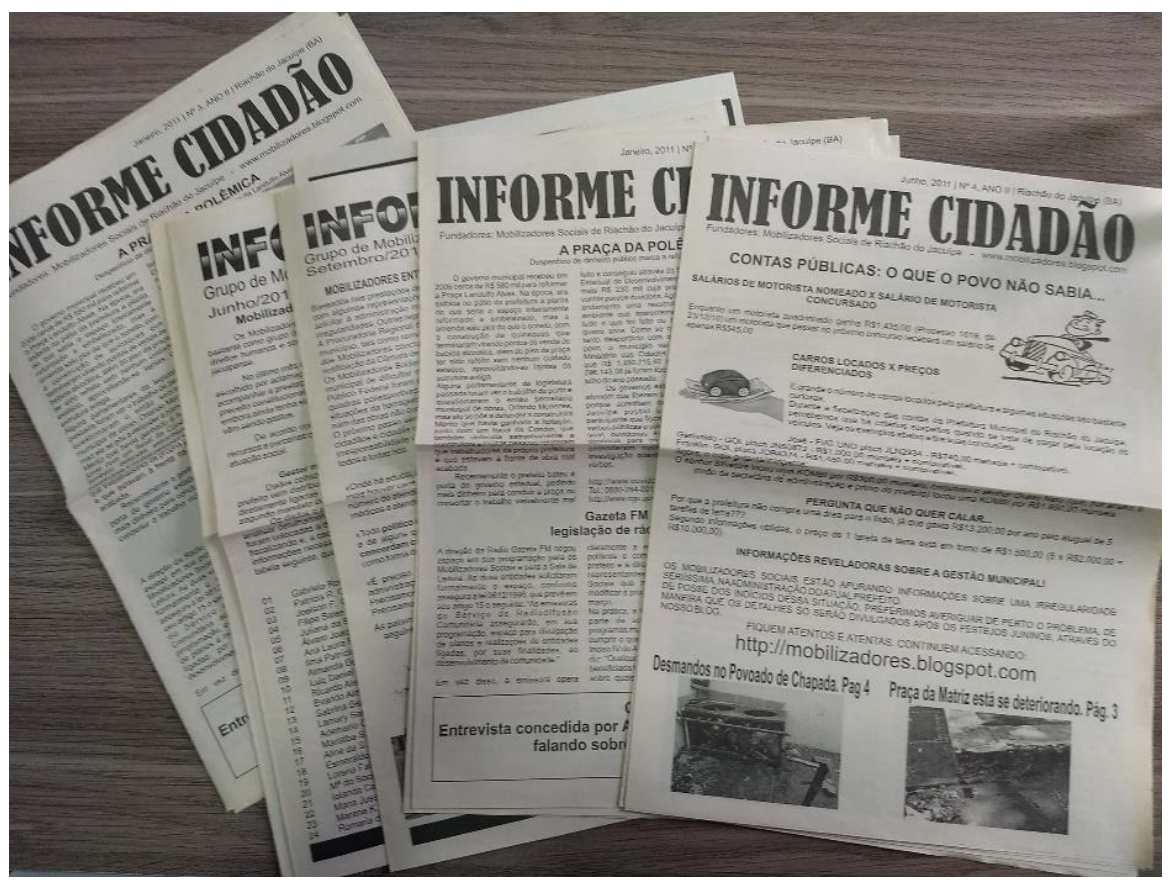

Fonte: Documento gentilmente cedido pelo movimento social.

A título de exemplificação sobre o conteúdo dos periódicos, a edição de ํㅡㄹ 3, ano II, de Janeiro de 2011 trazia entre suas manchetes: a) A Praça da Polêmica. Desperdício de Dinheiro Público marca a reforma da Landulfo Alves; b) Entendendo para viver melhor: Política e politicamente; c) Riachão, como anda sua educação?; d) Prefeito não consegue esclarecer o atraso na obra do abatedouro regional; e) Riachão- Rio Jacuípe pede socorro e população ribeirinha mais atenção!. Abaixo trecho da matéria intitulada "Vem aí o Controle Social das contas públicas em 2011: cidadania e participação" a fim fornecer ao leitor do presente estudo uma noção do teor do jornal:

Cidadania é participação consciente. Ser consciente da realidade em que se vive é de suma importância para a cidadania, pois a falta de consciência da realidade favorece a manipulação e prejudica a cidadania. Portanto, participar e ser consciente da realidade é buscar fazer valer nossa opinião e ajudar na conquista de nossos direitos. Cidadania é participação solidária, pois ninguém consegue ser cidadão sozinho e cidadã sozinha; ninguém é cidadão para si mesmo e cidadã para si mesma (...)

Queremos conclamar os leitores e as leitoras do INFORME CIDADÃo para participar com os Mobilizadores Sociais do acompanhamento das contas públicas em 2011, a partir de 15 de abril.

Neste sentido, é louvável o trabalho de informação, haja vista tratar-se de uma das características mais importante de um movimento social, qual seja a capacidade de gerar uma nova conscientização, de produzir saberes e inovações sociais. Aqui a importante lição de DALARI a respeito (1984, p. 51 e 91 apud GOHN 2013, p 28): “entre as mais eficientes formas de participação política estão os trabalhos de conscientização e organização".

Contudo, o movimento se afastou da proposta inicial de controle social em virtude de problemas que foram surgindo durante o trabalho, vejamos o depoimento de Luzia Oliveira: 
Talvez, porque, precisa de gente disponível, né?! Os horários, eu lembro na época... Mas tinha que ter os horários disponíveis que se não me engano eram na parte da manhã e da tarde. Mas que fizeram com bom êxito. Foram deixando, né! Não é que faltou vontade! Faltou mais por causa da queda do movimento que parou mais de se reunir. Faltou gente! Passou para outra gestão, se não me engano, em 2013, então era necessário fazer! Tomara que novas pessoas, inclusive a parte que me cabe enquanto cidadã, retome esse trabalho (Entrevista realizada em 09 de julho de 2019).

O mobilizador José Avelange, também narra outras dificuldades:

Por ocupações pessoais e também por discordâncias que é comum acontecer por ponto de vista político a gente passou a não contar mais com esse público participante. 0 trabalho foi sendo dificultado, mas o propósito inicial do grupo permaneceu. (...). Além do que algumas denúncias que foram feitas a partir da coleta desses dados da administração pública o pessoal se desiludiu porque não resultou em praticamente nada, até pelo contrário houve um momento que o Ministério Público passou até certo ponto a questionar as denúncias ao invés de dar cumprimento ao que se propunha na denúncia e essa é uma das razões para que as pessoas deixassem de participar (Entrevista realizada dia 23 de novembro de 2018).

Conscientes das dificuldades encontradas, mas também de que os propósitos do movimento, conforme as falas acima, permaneceram vivos, fizeram com que os Mobilizadores Sociais concentrassem os seus esforços na formação de novos atores sociais. 0 movimento, assim, direcionou seus esforços para uma capacitação política mais sólida a fim de orientar a atuação dos atores sociais. E nesse ponto se encontra o segundo momento do movimento, a fase da formação para a cidadania, vejamos a fala de José Avelange: "Aí a gente notou também que havia a necessidade de formação para que esse trabalho pudesse ser feito com mais qualidade...".

Dessa forma, em parceria com outro movimento social a "Sala de Leitura" e com a Paróquia local atualmente é ofertado um curso aberto, livre e gratuito a qualquer cidadão sobre Ciências Políticas. Segundo disposto no site dos Mobilizadores o curso tem por objetivo:

(...) capacitar as lideranças pastorais e outros interessados a encarar a política não mais como uma atividade que divide pessoas e grupos e sim como uma possibilidade de transformação positiva das realidades, o que não exclui a diferença de pontos de vista, mas ao contrário, os torna complementares e benéficos ${ }^{7}$.

A meta é que, ao final do percurso formativo, os participantes sejam capazes de compreender em profundidade a vida em sociedade, o funcionamento dos poderes, bem como a influência dos grupos de interesse e de pressão sobre cada um deles. Com essa compreensão, a tendência é diminuir a politicagem local, a aversão aos assuntos políticos e aumentar a participação de qualidade.

Segundo Vital Marinho, ator social, a proposta de formação é fundamental tendo em vista o baixo exercício da cidadania no município:

Uma formação voltada para a cidadania é a única garantia que a gente tem que um dia vamos sair do caos. Porque nós já estamos no fundo do poço, no aspecto de cidadania nós já ultrapassamos o fundo do poço. (...) A gente é formado para não ser cidadão. Para viver a subcidadania. Para a gente acreditar que aquele que tem mais dinheiro é

\footnotetext{
${ }^{7}$ Disponível em: http://mobilizadores.blogspot.com, s.d. Acesso em jun. 2019. 
mais correto, capaz, honesto... [...] Então não tem outra saída a não ser a formação de base, você chegar de casa em casa e tentar reunir as pessoas em uma associação comunitária. Tentar juntar o pobre, o desvalido para primeiro dizer a ele que ele é gente e o que é ser gente. Porque estamos vivendo uma situação de "sub-gente".

A problemática da qualificação para o exercício do controle social, também foi detectada por GOHN (2013, p.100) quando se dedicou a estudar a atuação dos conselhos gestores municipais, vejamos:

A participação, para ser efetiva, precisa ser qualificada, ou seja, não basta a presença numérica das pessoas porque o acesso está aberto. É preciso dotá-las de informações e de conhecimentos sobre o funcionamento das estruturas estatais. Não se trata, em absoluto, de integrá-la, incorporá-las à teia burocrática. Elas têm o direito de conhecer essa teia para poder intervir de forma a exercitar uma cidadania ativa, não regulada, outorgada, passiva;

A Figura 6 consiste em um dia de aula do curso analisada em atividade de campo $(05 / 11 / 2018)$ onde se observou que a metodologia consiste em aulas expositivas sobre conceitos de política, democracia, direitos humanos e cidadania, mediante recurso audiovisual e com a abertura de espaço para discussões entre participantes sob temas atuais no cenário local e nacional, assim como na troca de experiências.

Figura 3. Aula do curso de ciências políticas fornecida pelo movimento.

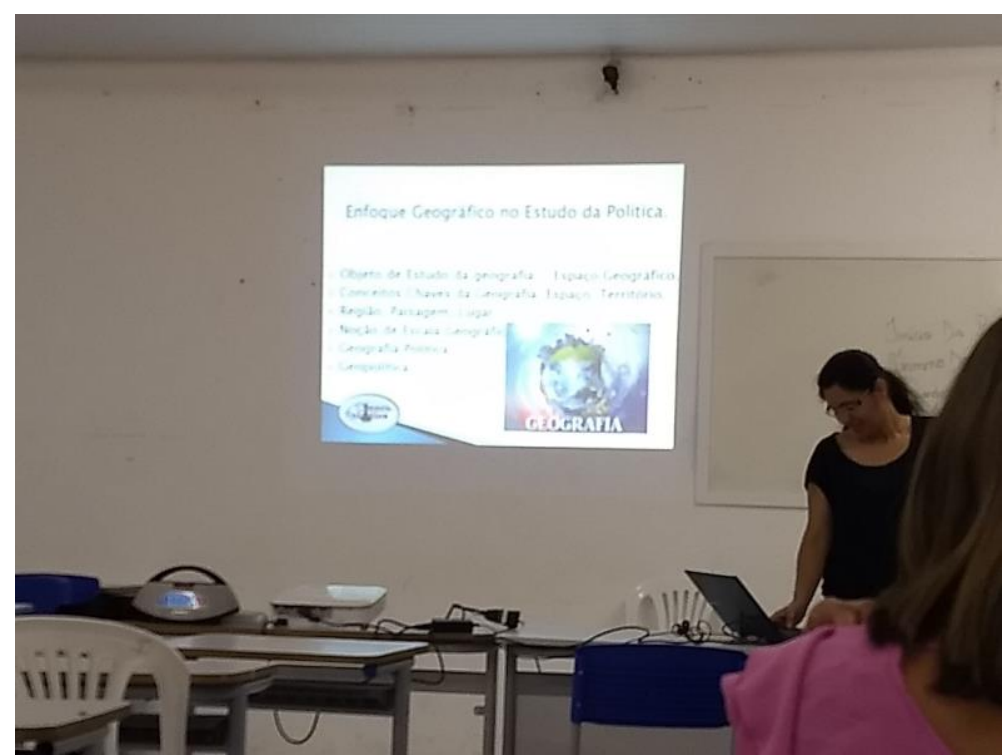

Fonte: Foto coletada em atividade de campo.

O caminho seguido pelo Movimento Social pode representar para uma visão rápida e superficial um caso de retrocesso, todavia é um caminho bem acertado na medida em que fornece aos cidadãos de Riachão do Jacuípe uma visão crítica de seu papel e da potencialidade que o movimento pode trazer, neste sentido é bem ilustrativa a opinião de Gohn (2010, p.16): 
Os movimentos sociais sempre tem um caráter educativo e de aprendizagem para seus protagonistas. Finalmente, os movimentos sociais na atualidade tematizam e redefinem a esfera pública, realizam parcerias com outras entidades da sociedade civil e política, tem grande poder de controle social e constroem modelos de inovações sociais, podendo portanto virem a ser matriz geradora de saberes.

Tal opinião é reforçada, sobretudo, quando a mudança de estratégia advém como uma resposta às dificuldades encontradas, demonstrando que o movimento tem articulação necessária não só para a melhoria da gestão pública, mas para a própria gestão. A saída encontrada pelos mobilizadores aponta para uma retomada das ações iniciais de controle social com maior estabilidade, trata-se de uma constatação obtida através da fala de José Avelange:

Eu acredito que para futuro os Mobilizadores podem voltar a efetuar esse papel de acompanhamento das contas públicas sim, é uma perspectiva que está prevista, mas para isto está investindo primeiro na formação, inclusive na formação humana para que a coisa seja feita com maturidade e resulte naquilo que se espera que também não é um denuncismo vazio, né! Mas algo que tenha fundamento que sirva para o desenvolvimento das pessoas da sociedade é nessa perspectiva! (Entrevista realizada no dia 23 de novembro de 2018).

Neste aspecto tem se que o movimento social apresenta uma interessante flexibilidade que lhe permite se adequar aos desafios impostos não só externos, mas também internos, o que dentro do importante papel social que exerce é fundamental para não esmaecer frente aos desafios que sempre podem surgir.

\section{RELAÇÕES COM O PODER PÚBLICO}

Os movimentos sociais têm a capacidade de promover um aprimoramento da democracia, da melhoria da qualidade da participação popular, pois ocupam o espectro chamado de público nãoestatal8. Todavia, a relação entre movimentos e o Estado é por vezes tensas, indo desde a colaboração, a tentativa de cooptação, mas também pelo confronto de interesses (DA SILVA, 2010).

Isto posto, compreendendo que os Mobilizadores Sociais se propõem a realizar o controle social dos poderes locais, faz-se necessário compreender as relações que o movimento estabeleceu com os poderes estatais.

Para realizar o controle das contas públicas era preciso que o poder municipal fornecesse os dados públicos da administração, conforme determina a Constituição Federal e a Lei Orgânica do Município, todavia segundo análise das denúncias realizadas pelo movimento, o Poder Executivo municipal em diversas oportunidades tentou impedir o processo de fiscalização, demonstrando o caráter conflituoso que a atuação do movimento social exercia sobre as relações de poder constituídas.

\footnotetext{
8 Segundo Bresser-Pereira (1998, p. 261) é um espaço entre o privado e o estatal onde: “(...)não se confunde com o estatal. 0 espaço público é mais amplo que o estatal, já que pode ser estatal ou não estatal.
} 
Isso porque na época as contas não eram disponibilizadas na forma digital e exigia do movimento além do conhecimento técnico para analisar os dados, mas também logística para organizar os documentos fornecidos, pois os mesmos, quando disponibilizados, estavam em desordem, conforme as Figuras 7 e 8.

Figura 4. Documentos disponibilizados de modo desordenado pelo Poder Executivo Municipal.

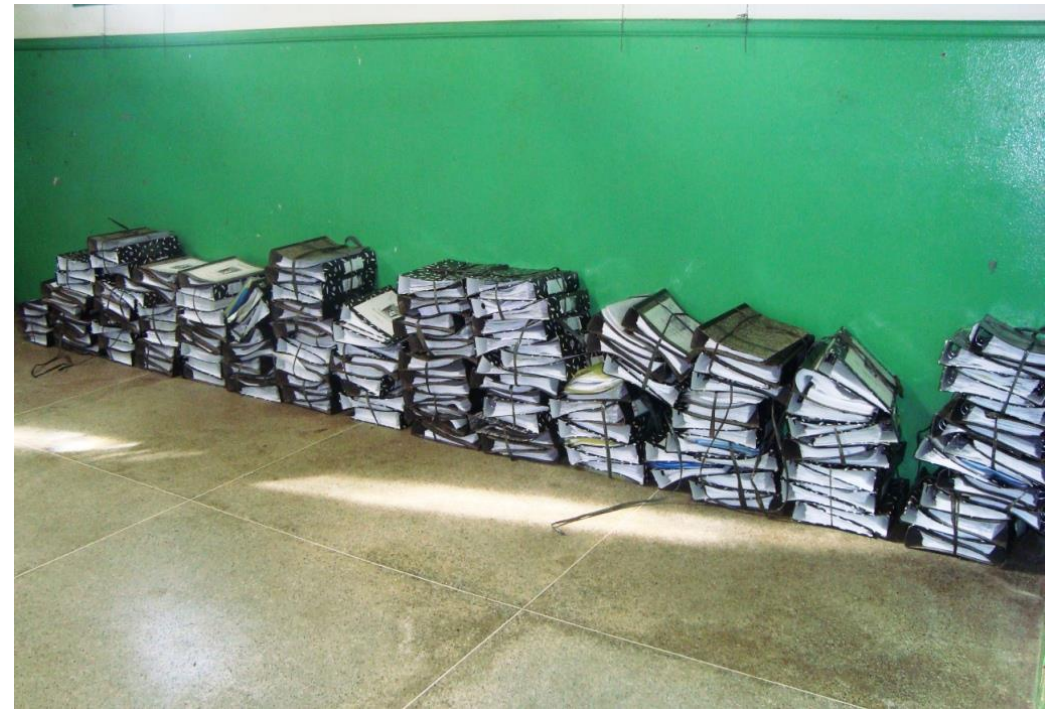

Fonte: Site http://mobilizadores.blogspot.com.

Figura 5. Mutirão para organizar os documentos fornecidos.

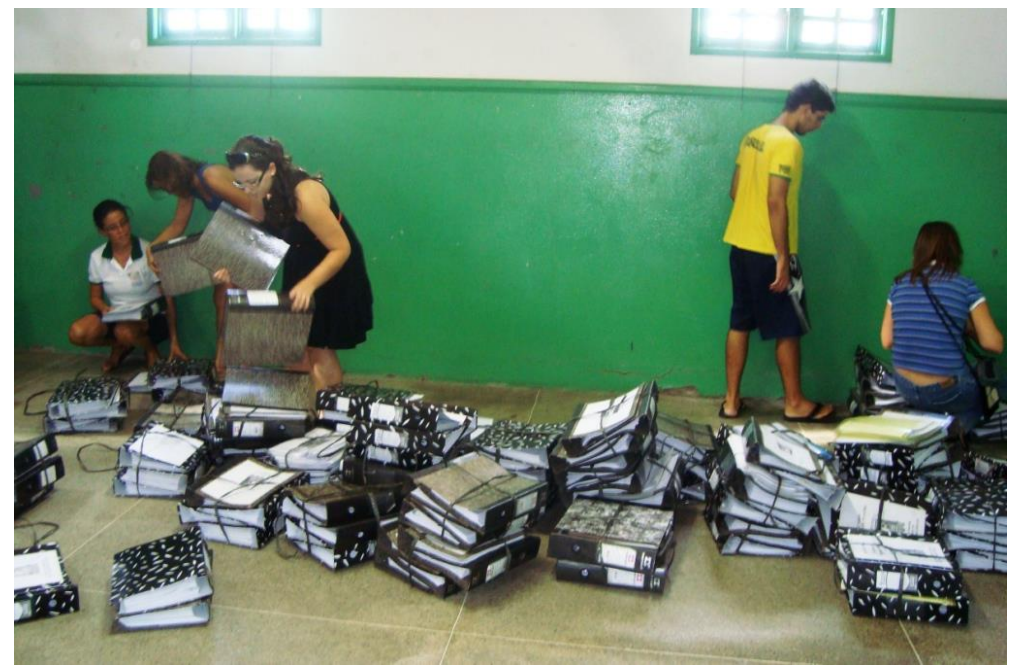

Fonte: Disponível no site do movimento social.

A atividade surtiu frutos na medida em que várias irregularidades foram detectadas e encaminhadas por meio de representações ao Ministério Público pra que se averiguasse e oferecesse a denúncia-crime ao Poder Judiciário.

Inicialmente os Mobilizadores Sociais encontraram no Ministério Público a parceria necessária para a realização de suas atividades para além da determinação legal na medida que forneceu 
formação técnica para os cidadãos em audiência pública em parceria com o Tribunal de Contas dos Municípios (TCM) a fim de auxiliar a superarem as dificuldades de compreender a linguagem técnica/burocrática e fomentar o controle social. Segundo depoimento da promotora de justiça Analízia Freitas, foi buscado realizar diversas audiências públicas a fim de subsidiar a participação popular e o controle social tendo em vista a ausência da cultura no município e da pouca transparência das contas públicas.

A Figura 9 demonstra o referido treinamento acima ofertado pelo TCM ao movimento social na Sala do Júri na Comarca de Riachão do Jacuípe:

Figura 6. Treinamento ofertado pelo Ministério Público e o Tribunal de Contas.



Fonte: Site do Ministério Público da Bahia. Título da matéria:

Fiscalização de contas públicas é incentivada em Riachão do Jacuípe.

Todavia, a fala expressa pelo ator social, José Avelange, já demonstra um desapontamento e desgaste com o Ministério Público e como uma das razões para o afastamento de alguns militantes:

Além do que algumas denúncias que foram feitas a partir da coleta desses dados da administração pública o pessoal se desiludiu porque não resultou em praticamente nada, até pelo contrário houve um momento que o Ministério Público passou até certo ponto a questionar as denúncias ao invés de dar cumprimento ao que se propunha na denúncia e essa é uma das razões para que as pessoas deixassem de participar.

Embora que, segundo a promotora, as críticas não encontram amparo tendo em vista que as denúncias para serem oferecidas ao Judiciário necessitam de um forte lastro probatório e com relação a morosidade, e ainda segundo ela, decorre da lentidão da justiça brasileira e de sua carência em recursos físicos e humanos.

A relação conflituosa não deveria haver razão para existir dentro de um Estado que se configura como republicano e democrático, contudo, é preciso fazer uma leitura de uma realidade 
onde há poucas décadas imperava práticas autoritárias derivadas do coronelismo, do patrimonialismo e do clientelismo. Trata-se de uma atividade emancipatória para o cidadão e de enfrentamento do status quo.

Na pesquisa realizada por DA SILVA (2005, p.114), a pesquisadora também detectou uma tensão entre os mandatários públicos e as atividades de cidadania empreendidas pelo padre Silvino na década de 1990, considerado um intruso:

\begin{abstract}
Os Anais da Câmara contêm inúmeras informações sobre a delimitação do espaço da "política" - recortado e arrumado conforme os interesses de manutenção das estruturas de poder, a partir das demandas eminentes do período. Nas narrativas do tempo do conflito, os políticos construíram táticas e estratégias para se defender ante as ameaças do pároco, tentando expurgar todos os intrusos.
\end{abstract}

As relações de tensão entre o Estado e movimentos sociais, não somente tendo como objeto de estudo os Mobilizadores Sociais e os poderes constituídos em Riachão do Jacuípe, demonstram que as ações de cidadania são legítimas e necessárias para o aperfeiçoamento da cidadania e da própria democracia.

\title{
CONSIDERAÇÕES FINAIS
}

Influenciados pelas práticas de cidadania exercida pelos sacerdotes católicos que chegaram a cidade de Riachão do Jacuípe e o hiato deixado pelos mesmos quando da suas saídas, cidadãos jacuipenses conscientes buscaram acompanhar com maior rigor e vigor os assuntos públicos do município.

O movimento produziu diversas denúncias, atuaram no campo da comunicação, participaram de audiências públicas promovidas pelo Ministério Público, articularam-se com outros movimentos locais e na formação para a cidadania.

Todavia, como nem tudo são flores, as dificuldades também surgiram, primeiramente com o próprio Poder Público, seja o Executivo ou o Legislativo que para além de não colaborar procuraram atrapalhar as ações do movimento, um fenômeno já observado pelo trabalho de Silva (2005) quando estudou a atuação dos religiosos na década de 1990.

Além disso, divergências políticas, desapontamentos, compatibilização de horário com atividades privadas e capacitação dos atores sociais também foram outros problemas enfrentados pelos Mobilizadores. Mas, ao invés de enfraquecer o movimento, fizeram com que os mesmos partissem para uma nova estratégia, atuando no campo da formação, despertando os "velhos" e formando novos atores sociais.

Neste sentido, a resistência perante as dificuldades, demonstra que de fato, como diz Gohn (2010) o povo não é uma massa "inerte", mas está sempre se articulando. 
Ao estudar o papel de um movimento social na gestão pública local se percebe o qual grande é o desafio proposto, enfrentando as relações de poder estabelecidos, dificuldades na gestão humana e de articulação política para exercer seu papel.

Tomando como referência o contexto político, não apenas da cidade de Riachão do Jacuípe, mas nacionalmente, faz-se necessário a atuação não somente dos Mobilizadores Sociais, mas a eclosão de vários "Mobilizadores" pelo Brasil a fim de extirpar velhas práticas políticas e propor uma gestão pública popular. Apesar do caráter "revolucionário" os movimentos sociais de controle e participação popular buscam uma melhor gestão da coisa pública e encaminham para o aprimoramento da democracia, vejamos a opinião de Britto (1992, p. 121): “(...) a participação popular não quebra o monopólio estatal da produção do Direito, mas obriga o Estado a elaborar o seu Direito de forma emparceirada com os particulares (individual ou coletivamente)".

Os movimentos sociais, nesse aspecto, são essenciais para o amadurecimento da democracia, sobretudo a brasileira que é jovem e carregada de vícios na gestão, e a servir de ponto de inovação, de proposição de demandas públicas e de aprimoramento, neste sentido é elucidativa a opinião de GOHN (2012):

Acreditamos que a importância da participação da sociedade civil se faz não apenas para ocupar espaços nas novas esferas públicas, antes dominadas por representantes de interesses econômicos, encravados no Estado e seus aparelhos. A importância se faz para democratizar a gestão pública, para se ter controle social e inverter as prioridades das administrações no sentido de políticas que atendam não apenas às questões emergenciais, mas políticas que contemplem o crescimento econômico com o desenvolvimento autossustentável das populações atendidas, assim como respeitem os direitos dos cidadãos(ãs) (GOHN, 2012, p. 37):

Os Mobilizadores Sociais vêm, portanto, buscando realizar um trabalho de cidadania, através da conscientização política da população local mediante atividades de educação, comunicação social, articulação e controle social da gestão pública de Riachão do Jacuípe, podendo servir de modelo, inspiração e de encorajamento para cidadãos críticos e conscientes de seu papel na sociedade a fim de se unirem em movimentos sociais que buscam a melhoria da coisa pública. E tal constatação é verificada na fala de Luzia:

Sinto essa necessidade, essa vontade de sempre estar sempre participando (...) porque eu digo que aprendi a ser gente fazendo cidadania em ação. Agradeço muito a esses movimentos, inclusive os Mobilizadores Sociais, que é de suma importância para uma sociedade mais igualitária (Entrevista realizada dia 09 de julho de 2019).

Assim sendo, os Mobilizadores Sociais, apesar dos desafios encontrados, apresentam uma militância fundamental para o amadurecimento das práticas públicas no município de Riachão do Jacuípe. Em sentido amplo, os movimentos sociais têm um papel fundamental na construção de uma gestão na perspectiva societal, conforme proposta de Paula (2016), e para a concretização da cidadania, da democracia e da justiça social. 


\section{REFERÊNCIAS}

BRASIL. Constituição da República Federativa do Brasil. Disponível em http://www.planato.gov.br. Acesso em 13 de dezembro de 2018.

BRESSER-PEREIRA, Luiz Carlos. Da administração pública burocrática à gerencial. In: Reforma do Estado e Administração Pública Gerencial. Editora Fundação Getúlio Vargas. Luiz Carlos BresserPereira, Peter Spink (orgs.) Rio de Janeiro. 1998.

BRITTO, Carlos Ayres Brito. Distinção entre "Controle Social do Poder" e "Participação Popular". Revista de Direito Administrativo. Rio de Janeiro. 1992.

CARVALHO, José Murilo de. Cidadania no Brasil. 0 longo Caminho. $3^{\text {a }}$ ed. Ed. Civilização Brasileira. Rio de Janeiro. 2002.

DA SILVA, Marinelia Sousa. "Padre não deve ser meter em política?" Conflitos de política e religião em Riachão do Jacuípe. Dissertação de mestrado. UFBA. Salvador. 2005. Disponível em: http://repositorio.ufba.br/ri/handle/ri/10550. Acesso em 12 de dezembro de 2018.

DA SILVA, Onildo Araújo. A influência recíproca na ação: o Estado e as associações no Território do Sisal. In: Agripino Souza Coelho Neto et.al (Orgs.). (GEO) grafias dos movimentos sociais. Editora UEFS. Feira de Santana. 2010.

PAULA, Ana Paula Paes de. Por uma nova gestão pública. Editora Fundação Getúlio Vargas. Rio de Janeiro. 2016.

PINHO, José Antônio Gomes de. Reforma do Aparelho do Estado: Limites do Gerencialismo Frente ao Patrimonialismo. Revista O\&S. v. 5. N. 5. Maio/Agosto. Salvador. 1998.

FERNANDES, Florestan. A Revolução Burguesa no Brasil. 5a edição. Editora Globo. São Paulo. 2006.

GENRO, Tarso. Crise da Democracia. Direito, Democracia direta e Neoliberalismo na Ordem Global. Editora Vozes. Petrópolis. 2002.

GOHN, Maria da Gloria. Conselhos Gestores e Participação Sociopolítica. Ciência Política. 4ํㅡㄴ Edição. Editora Cortez. São Paulo. 2013. Movimentos sociais e redes de mobilizações civis. Editora Vozes. Petrópolis. 2010.

IBGE. Panorama: Riachão do Jacuípe. Disponível em: https://cidades.ibge.gov.br/brasil/ba/riachao-dojacuipe/panorama. Acesso em: 22 de dezembro de 2018.

JOAO PAULO II, Papa. Carta Encíclica Sollicitudo Rei Socialis. Disponível em: http://w2.vatican.va/content/john-paulii/pt/encyclicals/documents/hf_jpii_enc_30121987_sollicitudo-rei-socialis.html. Acesso em: 11 de julho de 2019.
JUNIOR, Alcides Domingues Leite. Desenvolvimento e Mudanças no Estado Brasileiro. Editora USFC. Florianópolis. 2006.

MARQUES, Cláudia. MIRAGEM, Bruno. O novo direito privado e a proteção dos vulneráveis. Editora RT. 2014.

MATIAS-PEREIRA, José. Manual de Gestão Pública Contemporânea. Editora Atlas. São Paulo. 2016.

MAZZEO, Antonio Carlos. Estado e Burguesia no Brasil. Origens da autocracia burguesa. Oficina de Livros. Belo Horizonte. 1989.

MINTZBERG, Henry. Administrando governos, governando administrações. Revista do Serviço Público. Ano 49. № 5. 1998.

RIACHÃO DO JACUÍPE. Lei Orgânica Municipal de Riachão do Jacuípe. Disponível em: http://www.riachaodojacuipe.ba.leg.br/leis/leiorganica-municipal/lei-organiamunicipal.pdf/view. Acesso em: 13 de dezembro de 2018.

SANTOS, Milton. O espaço da cidadania e outras reflexões. Coleção: O Pensamento Político Brasileiro. V.3. Fundação Ulysses Guimarães. Porto Alegre. 2011.

\section{Documentos}

Estatuto Social, documentos, petições, jornais, atas e fotografias gentilmente cedidos pelos "Mobilizadores Sociais de Riachão do Jacuípe".

\section{Entrevistas}

ANALÍZIA FREITAS, promotora de justiça.

Entrevista realizada em 16 de julho de 2019.

JOSÉ AVELANGE, ator social. Entrevista realizada em 23 de novembro de 2018.

LUZIA, mobilizadora social. Entrevista realizada em 09 de julho de 2019.

VITAL MARINHO, ator social. Entrevista realizada em 16 de julho de 2019. 